\title{
THE INFLUENCE OF URBAN PARK GREEN SPACES, PLANT MATERIAL SPECIFICATIONS AND SPATIAL DESIGN ORGANIZATION AND PATTERN TOWARDS CARBON SEQUESTRATION RATE
}

\author{
OTHMAN, R. ${ }^{1 *}-$ SUID, S. ${ }^{1}-$ MOHD NOOR, N. F. ${ }^{1}-$ BAHARUdDIN, Z. M. ${ }^{1}-$ HASHIM, K. S. H. Y. ${ }^{2}$ \\ - LUKMAN HAKIM MAHAMOD, L. H. ${ }^{3}$ \\ ${ }^{1}$ International Institute for Halal Research and Training (INHART) \\ Department of Landscape Architecture, Kulliyyah of Architecture and Environmental Design \\ (KAED), International Islamic University Malaysia, 53100 Kuala Lumpur, Malaysia \\ ${ }^{2}$ Department of Urban \& Regional Planning, Kulliyyah of Architecture and Environmental \\ Design (KAED), International Islamic University Malaysia, 53100 Kuala Lumpur, Malaysia \\ ${ }^{3}$ Department of Quantity Surveying, Kulliyyah of Architecture and Environmental Design \\ (KAED), International Islamic University Malaysia, 53100 Kuala Lumpur, Malaysia \\ Corresponding author \\ e-mail: rashidi@iium.edu.my; phone: +60-126-644-772; fax: +60-361-964-864
}

(Received 24 ${ }^{\text {th }}$ Jan 2019; accepted $3^{\text {rd }}$ May 2019)

\begin{abstract}
Urban parks planning and management is a crucial issue in the context of the urban environment and community development by creating space for social interactions, recreation, aesthetics and provide natural habitats. Apart from that, the value of the ecological functions such as air purification, storm water regulation and carbon storage are also crucial for biodiversity conservation within the urban context. This study provides a case study of the quantification of carbon sequestration rate by a selected urban park with a hybrid design landscape setting in Putra Heights, Mukim Damansara, Selangor. The carbon sequestration rate was calculated by biomass equations, using field data inventory, measurements, plan analysis and survey data analysis. This study aimed to discuss the influence of urban park green spaces, plant materials specifications and spatial design organization and pattern towards carbon sequestration rate. The significant outcome of this study is the determination of key factors that influenced the Carbon Sequestration Rate. This study proved that higher plants specification plays an important role in sequestering more carbon. The larger green area also contributes to higher carbon sequestration rate. These findings will become a novel landscape design approach to neutralize carbon emission with cost-effective and environmentally friendly.
\end{abstract}

Keywords: carbon emission, air pollution, green technology, landscape design, urban landscape

\section{Introduction}

Recently, urban greenery systems have been promoted as a climate change mitigation method (Velasco et al., 2016) as urban vegetation reduces the carbon dioxide $\left(\mathrm{CO}_{2}\right)$ concentration of the atmosphere through photosynthesis and by carbon storage via plant growth. The greatest available green spaces for city residents are urban parks (Ehnat, 2011; Gratani et al., 2016). Urban parks have been identified as one of the most important components of cities and had an evolving role in the life of city residents. Urban parks help decrease carbon emission levels in cities (Sadeghian, 2013). Trees act as a sink for $\mathrm{CO}_{2}$ by fixing carbon during photosynthesis and storing carbon as biomass (Nowak, 2013). According to Shahidan (2015), plants can filter heat and reduce radiation thus cooling off the urban environment. Therefore, urban park due to its 
conditions that are covered with plants is more likely beneficial to reduce urban heat island effect. Urban heat island effect is caused by the large areas of heat-absorbing surfaces, in a combination of high energy use in cities (Sadeghian, 2013).

However, the rapid wave of urbanization in recent decades foresees the high potential for increasing energy demand and severe environmental concerns, simultaneously. Furthermore, it is expected that by 2020, 3 quarters of the Malaysian population will be living in urban areas (Tenth Malaysia Plan, 2010). According to the Department of Statistics Malaysia (2011), in tandem with Malaysia's rapid development, the proportion of urban population increased to 71.0 percent in 2010 compared with 62.0 percent in 2000. One of the state in Malaysia with a high level of urbanization was Selangor with 91.4 percent. A significant increase in the urban population in a short span of time creates various problems, especially environmental problems. Air and noise pollutions are generally considered as a major concern in urban areas.

The recent study by Shahbaz et al. (2015) found strong causal links between urbanization and energy consumption in Malaysia. Therefore, there is a possibility that the urbanization also has direct or indirect relation with carbon dioxide emission. Thus, having an urban park will help to mitigate climate change by functioning as a carbon sink to reduce air pollutant level and sequestering atmospheric $\mathrm{CO}_{2}$. Carbon sequestration is defined as a method or process of moderating carbon dioxide in the atmosphere to stop it from being polluted (Singh, 2013). This method will contribute to mitigating global warming as it will capture and store carbon dioxide gas in a particular process (Rackley, 2010).

Although the impacts of urban trees thus have been studied rather extensively, at least through urban air quality models, there is a suggestion that research specifically on urban parks has been limited so far (Pataki et al., 2011; Yin et al., 2011). The case study for this research is Putra Heights Neighbourhood Park (Fig. 1) with hybrid design landscape setting located at Selangor, Malaysia. Thus, the objective of this research is to assess the influence of urban park green spaces, plant materials specifications and spatial design organization and pattern towards carbon sequestration rate.

\section{Material and methods}

\section{Study area description}

Selected site study area (Fig. 1) located at Neighborhood Park, Putra Heights, Mukim Damansara, Daerah Petaling, Selangor ( $\left.3^{\circ} 01^{\prime} 13.1^{\prime \prime N} 101^{\circ} 34^{\prime} 31.7 " E\right)$, a rapidly urbanized and populated city surrounded by highly developed residential areas with the Light Rail Transit (LRT) and ELITE highway located nearby. With the overall park area of 10.45 acres, this urban park serves as a recreational park to the surrounding neighbourhood area.

\section{Site inventory and plan analysis}

The first method applied was through site inventory and analysis. The girth of each plants species was measured conventionally at the breast height $(\mathrm{GBH})$ i.e. near about $1.32 \mathrm{~m}$ above the ground surface as well as overall plants heights (Moumita, 2015). For calculating the total built-up area and green area of the park, the base map of Putra Heights Neighborhood Park was obtained from the authority. Plan analysis was 
conducted to determine the overall park design structure, planting composition and also spatial design organization and pattern. Apart from that, the bill of quantities of landscape plants was also retrieved in order to identify the exact quantity of the plant materials and to identify the plant specifications including the overall height and breast height diameter of plants for determination of age. Next, the current carbon sequestration rate (CSR) on every planting species was calculated using the carbon calculator formula stated in Table 1 below. In calculating the carbon sequestration rate of the selected site study area, there are few matters needed to be considered as the rate for carbon sequestration vary greatly depending on a few factors such as tree species, age/stage of tree, composition/density of tree, location/condition of the tree and type of soil (Othman, 2016).

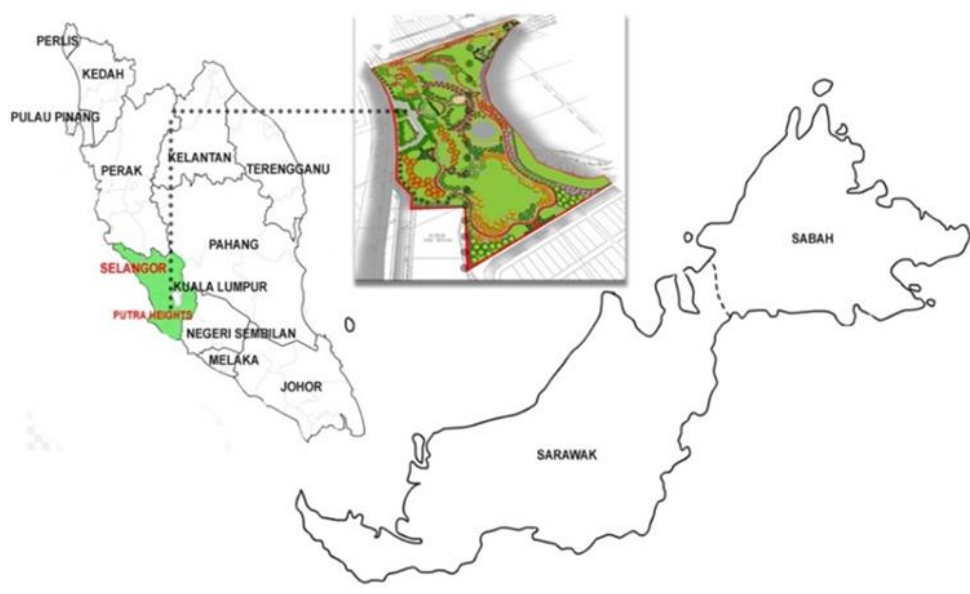

Figure 1. Base map showing the study area located at Putra Heights Neighbourhood Park, Selangor, Malaysia

Table 1. The formula to calculate carbon sequestration rate (CSR)

\begin{tabular}{c|c}
\hline CSR formula for tree and shrub & CSR formula for turf, climber and groundcover \\
\hline Total Green Weight $(\mathrm{TGW}): 0.25 \mathrm{D}^{2} \mathrm{H}(1.2)$ & Total Dry Weight $(\mathrm{TDW}): 0.56 \times$ area $\left(\mathrm{m}^{2}\right)$ \\
Total Dry Weight $(\mathrm{TDW}): \mathrm{TGW} \times 0.725$ & Total Carbon Weight $(\mathrm{TCW}): \mathrm{TDW} \times 0.427$ \\
Total Carbon Weight $(\mathrm{TCW}): \mathrm{TDW} \times 0.5$ & Total $\mathrm{CO}_{2}$ Weight $\left(\mathrm{TCO}_{2} \mathrm{~W}\right): \mathrm{TCW} \times 3.6663$ \\
Total $\mathrm{CO}_{2}$ Weight $\left(\mathrm{TCO}_{2} \mathrm{~W}\right): \mathrm{TCW} \times 3.6663$ & $\mathrm{D}=$ Diameter of the trunk; $\mathrm{H}=$ Height of the tree \\
\hline
\end{tabular}

\section{Results and discussion}

\section{Carbon Sequestration Rate at Putra Heights Neighbourhood Park}

Tables 2-6 and Fig. 2 portrayed the amount of $\mathrm{CO}_{2}$ sequestered by different types of plant's categories and species. The carbon sequestration value for all planting species from each planting categories was then calculated. The highest amount of carbon sequestration rate is from the turf category (Axonopus compressus). The total amount of $\mathrm{CO}_{2}$ sequestered by this turfing species is $31530 \mathrm{kgCO}_{2} \mathrm{e}$ compared to other plants categories such as trees $\left(11438.83 \mathrm{kgCO}_{2} \mathrm{e}\right)$, orchard trees $\left(272.80 \mathrm{kgCO}_{2} \mathrm{e}\right)$, palms $\left(1264.57 \mathrm{kgCO}_{2} \mathrm{e}\right)$ and shrubs $\left(943.19 \mathrm{kgCO}_{2} \mathrm{e}\right)$. From Table 1, it can be depicted that tree species of Samanea saman sequestered the highest total amount of $\mathrm{CO}_{2}$ of 
$1937.93 \mathrm{kgCO}_{2} \mathrm{e}$. Meanwhile, Neodypsis leptocheilos ranked as the highest sequester agent for palm category with the amount of $427.32 \mathrm{kgCO}_{2} \mathrm{e}$. Eugenia oleana has been classified as the highest sequester agent under shrubs categories that sequestered $692.06 \mathrm{kgCO}_{2} \mathrm{e}$.

Table 2. Carbon sequestration rate produced by trees at Putra Heights Neighbourhood Park

\begin{tabular}{c|c|c|c|c|c|c|c}
\hline No & Species & $\begin{array}{c}\text { Overall } \\
\text { Height } \\
\text { (Feet) }\end{array}$ & $\begin{array}{c}\text { Trunk } \\
\text { Diameter } \\
\text { (Inch) }\end{array}$ & $\begin{array}{c}\text { Quantity } \\
\text { (Nos) }\end{array}$ & Age & $\begin{array}{c}\text { tCO } \mathbf{e} / \\
\text { unit }\end{array}$ & $\begin{array}{c}\text { Total } \\
\mathbf{C O}_{\mathbf{2}} \mathbf{e} \\
\text { (kg) }\end{array}$ \\
\hline 1. & Agathis borneensis & 13.12 & 1.82 & 33 & 5.4 & 0.001 & 48.03 \\
2. & Azadirachta excelsa & 22.97 & 6.97 & 40 & 5.4 & 0.037 & 1494.91 \\
3. & Bucida molineti & 32.81 & 7.11 & 36 & 6 & 0.050 & 1799.78 \\
4. & Caesalpinia ferrea & 19.69 & 4.77 & 14 & 5.6 & 0.014 & 202.56 \\
5. & Cinnamomum iners & 19.69 & 4.87 & 35 & 5.6 & 0.015 & 527.85 \\
6. & Cratoxylum formosum & 16.4 & 4.01 & 25 & 6 & 0.008 & 198.72 \\
7. & Dalbergia latifolia & 19.69 & 4.83 & 35 & 5.2 & 0.016 & 559.15 \\
8. & Eugenia grandis & 32.81 & 5.01 & 50 & 6 & 0.025 & 1241.15 \\
9. & Fagraea fragrans & 19.69 & 3.55 & 27 & 5.6 & 0.008 & 216.37 \\
10. & Hopea odorata & 22.97 & 3.59 & 35 & 5.6 & 0.010 & 334.62 \\
11. & Mesua ferrea & 19.69 & 3.11 & 11 & 5.6 & 0.006 & 67.65 \\
12. & Pongamia pinnata & 26.25 & 4.84 & 47 & 5.6 & 0.020 & 933.37 \\
13. & Samanea saman & 32.81 & 8.2 & 34 & 7 & 0.057 & 1937.93 \\
14. & Saraca cauliflora & 19.69 & 3.76 & 10 & 5.6 & 0.009 & 89.90 \\
15. & Schizolobium parahyba & 29.53 & 7.42 & 20 & 5.6 & 0.053 & 1050.11 \\
16. & Spathodea campanulata & 16.4 & 5.31 & 34 & 6 & 0.014 & 473.90 \\
17. & Tristaniopsis whiteana & 16.4 & 2.54 & 28 & 5.6 & 0.003 & 95.68 \\
18. & Xanthostemon chrysanthus & 19.69 & 2.63 & 38 & 5.6 & 0.004 & 167.14 \\
\hline
\end{tabular}

Table 3. Carbon sequestration rate produced by orchard trees at Putra Heights Neighbourhood Park

\begin{tabular}{c|c|c|c|c|c|c|c}
\hline No & Species & $\begin{array}{c}\text { Overall } \\
\text { Height } \\
\text { (Feet) }\end{array}$ & $\begin{array}{c}\text { Trunk } \\
\text { Diameter } \\
\text { (Inch) }\end{array}$ & $\begin{array}{c}\text { Quantity } \\
\text { (Nos) }\end{array}$ & Age & $\begin{array}{c}\text { tCO } \mathbf{e} / \\
\mathbf{u n i t}\end{array}$ & $\begin{array}{c}\text { Total } \\
\mathbf{C O}_{\mathbf{2}} \mathbf{e} \\
(\mathbf{k g})\end{array}$ \\
\hline 1. & Artocarpus altilis & 13.12 & 4.97 & 3 & 5 & 0.0117 & 35.17 \\
2. & Averrhoa bilimbi & 13.12 & 2 & 5 & 5 & 0.0019 & 9.49 \\
3. & Averrhoa carambola & 13.12 & 2.83 & 5 & 5 & 0.0038 & 19.00 \\
4. & Euphoria malaiense & 13.12 & 2.28 & 3 & 5 & 0.0025 & 7.40 \\
5. & Garcinia mangostana & 13.12 & 1.98 & 10 & 5 & 0.0019 & 18.60 \\
6. & Lansium domensticium & 13.12 & 2.34 & 5 & 5 & 0.0026 & 12.99 \\
7. & Mangifera indica & 13.12 & 3.61 & 22 & 5 & 0.0062 & 136.06 \\
8. & Spondias cytherea & 13.12 & 3.46 & 6 & 5 & 0.0057 & 34.09 \\
\hline & & & & & & & $\mathbf{2 7 2 . 8 0}$ \\
\hline
\end{tabular}

Table 4. Carbon sequestration rate produced by palms at Putra Heights Neighbourhood Park

\begin{tabular}{c|c|c|c|c|c|c|c}
\hline No & Species & $\begin{array}{c}\text { Overall } \\
\text { Height } \\
\text { (Feet) }\end{array}$ & $\begin{array}{c}\text { Trunk } \\
\text { Diameter } \\
\text { (Inch) }\end{array}$ & $\begin{array}{c}\text { Quantity } \\
\text { (Nos) }\end{array}$ & Age & $\begin{array}{c}\mathbf{t C O}_{\mathbf{2}} \mathbf{e} / \\
\mathbf{u n i t}\end{array}$ & $\begin{array}{c}\text { Total } \\
\mathbf{C O}_{\mathbf{2}} \mathbf{e} \\
\mathbf{( k g )}\end{array}$ \\
\hline 1. & Cocos nucifera 'dwarf' & 11.48 & 6.67 & 10 & 8 & 0.012 & 115.46 \\
2. & Livistonia rotundifolia & 26.25 & 7.08 & 10 & 8 & 0.030 & 297.46 \\
3. & Neodypsis leptocheilos & 13.12 & 6.93 & 30 & 8 & 0.014 & 427.32 \\
4. & Ptychosperma macarthurii & 11.48 & 3.54 & 14 & 5 & 0.005 & 72.85 \\
5. & Wodyetia bifurca & 14.76 & 8.38 & 15 & 8 & 0.023 & 351.48 \\
\hline & & & & & & $\mathbf{1 2 6 4 . 5 7}$ \\
\hline
\end{tabular}


Table 5. Carbon sequestration rate produced by shrubs at Putra Heights Neighbourhood Park

\begin{tabular}{c|c|c|c|c|c|c|c}
\hline No & Species & $\begin{array}{c}\text { Overall } \\
\text { Height } \\
\text { (Feet) }\end{array}$ & $\begin{array}{c}\text { Trunk } \\
\text { Diameter } \\
\text { (Inch) }\end{array}$ & $\begin{array}{c}\text { Quantity } \\
\text { (Nos) }\end{array}$ & Age & $\begin{array}{c}\mathbf{t C O}_{\mathbf{2}} \mathbf{e} / \\
\text { unit }\end{array}$ & $\begin{array}{c}\text { Total } \\
\mathbf{C O}_{\mathbf{2}} \mathbf{e} \\
(\mathbf{k g})\end{array}$ \\
\hline 1. & Eugenia oleana & 8.2 & 2 & 700 & 6 & 0.0010 & 692.06 \\
2. & Raphis multifida & 3.94 & 1 & 105 & 5 & 0.0001 & 14.96 \\
3. & Murraya paniculata & 2.95 & 1 & 240 & 5 & 0.0001 & 25.61 \\
4. & Bougainvillea & 2.95 & 1 & 300 & 5 & 0.0001 & 32.01 \\
5. & Codiaeum variegatum & 2.95 & 1 & 180 & 5 & 0.0001 & 19.21 \\
6. & Dracaena marginata 'bicolor & 3.28 & 1 & 80 & 5 & 0.0001 & 9.49 \\
7. & Duranta erecta 'gold' & 2.95 & 1 & 475 & 5 & 0.0001 & 50.68 \\
8. & Hibiscus rosa sinensis & 3.28 & 1 & 264 & 5 & 0.0001 & 31.32 \\
9. & Ixora cultivar & 3.28 & 1 & 320 & 5 & 0.0001 & 37.96 \\
10. & Osmoxylum lineare & 2.95 & 1 & 280 & 5 & 0.0001 & 29.88 \\
\hline & & & & & & $\mathbf{9 4 3 . 1 9}$ \\
\hline
\end{tabular}

Table 6. Carbon sequestration rate produced by turf at Putra Heights Neighbourhood Park

\begin{tabular}{c|c|c|c}
\hline No & Species & Area $\left(\mathbf{m}^{2}\right)$ & Total $\mathbf{C O}_{\mathbf{2}} \mathbf{e}(\mathbf{k g})$ \\
\hline 1. & Axonopus compressus & 35,970 & 31530.00 \\
\hline & & & $\mathbf{3 1 5 3 0 . 0 0}$ \\
\hline
\end{tabular}

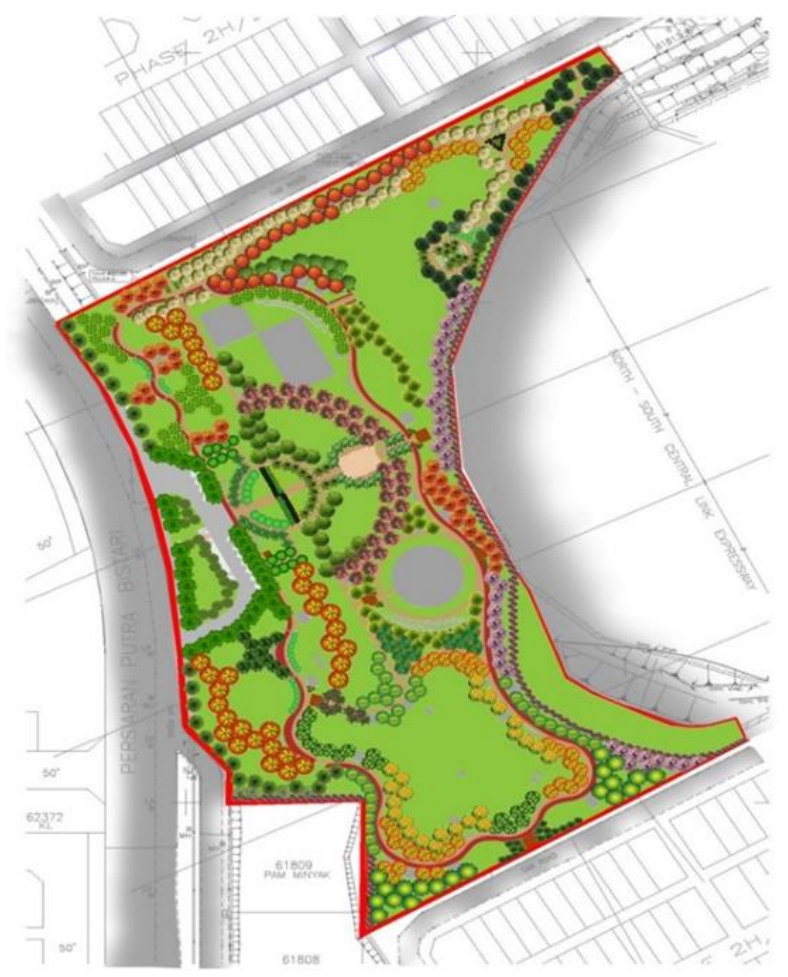

Figure 2. Planting plan at Putra Heights Neighbourhood Park

From Fig. 3, it can be depicted that the highest value represents as an effective agent to sequester carbon is from turf category $\left(31530 \mathrm{kgCO}_{2} \mathrm{e}\right)$. The amount is tremendously high compared to other planting categories. At this particular site, turfing category 
(Axonopus compressus) acts as a dominant Carbon Sequestration Rate (CSR) agent which contribute the highest CSR value due to the large coverage area for planted turfing. Meanwhile, trees category has become the second highest CSR agent that sequester $11438.83 \mathrm{kgCO}_{2} \mathrm{e}$, followed by palms $\left(1264.57 \mathrm{kgCO}_{2} \mathrm{e}\right)$, shrubs $\left(943.19 \mathrm{kgCO}_{2} \mathrm{e}\right)$ and the least CSR value represented by orchard tree category which sequestered $272.80 \mathrm{kgCO}_{2} \mathrm{e}$ of carbon dioxide.

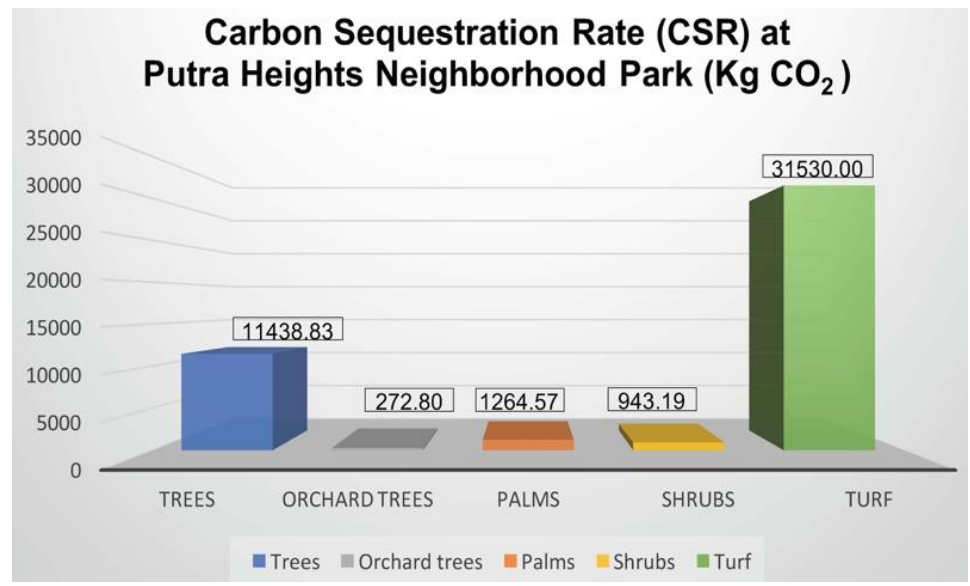

Figure 3. Carbon sequestration rate produced by a different type of planting category at Neighbourhood Park, Putra Heights

\section{Total Park Area, Green Area and Built Up Area of Neighbourhood Park}

In calculating the total park area, green area and built-up area of the park, the base map is obtained from the authorities (Fig. 4). The summary of the findings is presented in Table 7. According to Table 7, it can be found that the total park area is $42,288 \mathrm{~m}^{2}$, covered majority by a green area with the percentage of $87 \%\left(36760 \mathrm{~m}^{2}\right)$ and covered only $13 \%$ with the built-up area $\left(5528 \mathrm{~m}^{2}\right)$. According to Table 8 , the green area consists of soft landscape plantings which categorized as trees, palms, shrubs and turfing while the built-up area consists of the parking area, hard landscape components such as pedestrian walkways, jogging track, open plaza, wakaf, courts and children playground. Putra Heights Neighborhood Park is perceived to have a greener area than built up area.

This formula is created in order to identify the minimum amount of carbon sequestration rate required in every 1 meter square. For example, Malaysia's carbon emission is predicted at around 285.73 million tonnes by the year 2020 (Safaai et al., 2011):

$$
\frac{285.73 \text { million tonnes }}{330,803 \mathrm{~km}^{2}}=\frac{x}{1 \mathrm{~km}^{2}}
$$

$$
\begin{gathered}
1 \mathrm{~km}^{2} \times 285730000 \text { tonnes } \mathrm{km}^{2}=x\left(330,803 \mathrm{~km}^{2}\right) \\
x=285730000 \text { tonnes } \mathrm{km}^{2} / 330803 \mathrm{~km}^{2} \\
x=863.746 \text { tonnes per } \mathrm{km}^{2} / 1000000 \\
\underline{\mathbf{1 m}^{2}=\mathbf{0 . 0 0 0 8 6 3} \text { tonnes } / \mathbf{0 . 8 6 3} \mathbf{~ k g ~ C O}} \mathbf{~}
\end{gathered}
$$


From the calculation above, every $1 \mathrm{~m}^{2}$ of Malaysia should sequester minimum of $0.863 \mathrm{kgCO}_{2}$ emissions. Next, the amount will be multiplied by the total area of the site. Hence, Putra Heights Neighbourhood Park sequestered $1.077 \mathrm{Kg} \mathrm{CO}_{2}$ for every $1 \mathrm{~m}^{2}$, which is more than the amount of $\mathrm{CO}_{2}$ that it should sequester.

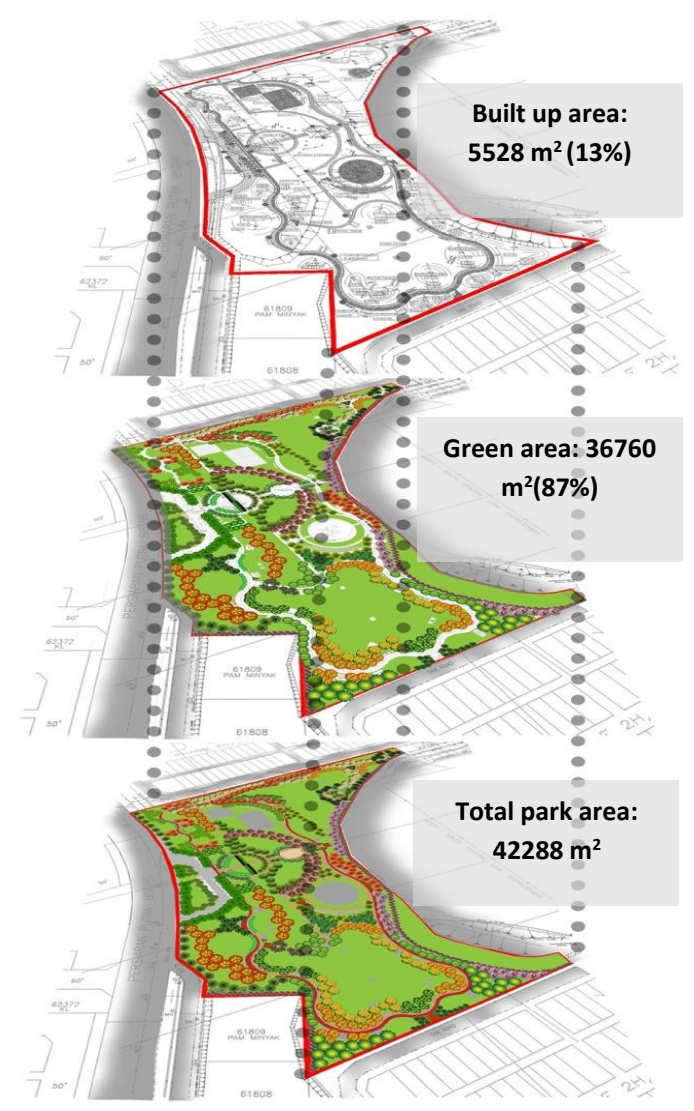

Figure 4. Distribution of total park area, green area and built up

Table 7. Components of Putra Heights Neighbourhood Park

\begin{tabular}{c|c|c}
\hline & Area $\left(\mathbf{m}^{\mathbf{2}}\right)$ & Percentage $\mathbf{( \% )}$ \\
\hline Total built-up area & $\mathbf{5 , 5 2 8}$ & $\mathbf{1 3}$ \\
\hline Parking Area & 1055 & 2.48 \\
\hline Hard Landscape Elements: & & 4.70 \\
\hline Pedestrian walkways & 2000 & 1.72 \\
Jogging track & 730 & 0.21 \\
Reflexology path & 90 & 0.76 \\
Open plaza & 325 & 0.23 \\
Wakaf/Gazebo & 96 & 1.72 \\
Basketball \& futsal court & 732 & 1.18 \\
Children playground & 500 & $\mathbf{8 7}$ \\
\hline Total green area & $\mathbf{3 6 7 6 0}$ & 1.63 \\
\hline Trees and palms & 690 & 0.24 \\
Shrubs & 100 & 85.13 \\
\hline Turfing & 35970 & $\mathbf{1 0 0}$ \\
\hline Total Park Area & $\mathbf{4 2 2 8 8}$ & \\
\hline
\end{tabular}


Table 8. Distribution of plant's category and quantity, carbon sequestration rate value and $\mathrm{CO}_{2}$ sequestered per $\mathrm{m}^{2}$

\begin{tabular}{c|c|c|c}
\hline Plant's Category & Plant's Quantity & $\begin{array}{c}\text { CSR Value } \\
(\mathbf{k g C O} \mathbf{C})\end{array}$ & $\begin{array}{c}\mathbf{C O}_{2} \text { Sequestered }_{\mathbf{2}} \\
\text { per } \mathbf{~ m}^{\mathbf{2}}\left(\mathbf{k g C O}_{\mathbf{2}}\right)\end{array}$ \\
\hline Trees & $552 \mathrm{nos}$ & 11438.83 & 0.270 \\
Orchard trees & $59 \mathrm{nos}$ & 272.80 & 0.006 \\
Palms & $79 \mathrm{nos}$ & 1264.57 & 0.030 \\
Shrubs & $2944 \mathrm{nos}$ & 943.19 & 0.022 \\
Turf & $35970 \mathrm{~m}^{2}$ & 31530.00 & 0.746 \\
\hline Total CSR & & $\mathbf{4 5 4 4 9 . 3 9}$ & $\mathbf{1 . 0 7 7}$ \\
\hline Total park area $-\mathbf{4 2 2 8 8} \mathbf{~ m}^{\mathbf{2}}$ & & & \\
\hline
\end{tabular}

\section{Factors Influencing Total Carbon Sequestration Rate}

Results showed that different planting specification contributes to the different amount of carbon sequestration rate even though there are from the same plant's category. According to Mandal et al. (2016), the effect of carbon sequestration varies from the plant species, for instance, parks with trees and shrubs have the most efficient carbon sequestration effect. Therefore, the findings proved that higher plants specification contributes to greater CSR value. For example, as the trees grow older, the tree trunk becomes taller and the trunk diameter becomes bigger, the greater carbons are being absorbed by the plants provided with the plants are being maintained and taken care with the proper landscape maintenance practice applied. Apart from that, planting quantity also has interrelated to influence the total carbon sequestration rate. Results proved that planting with larger quantity and higher specifications have a greater capability to sequester the higher amount of carbon dioxide. The difference between the ability of each plants category to sequester carbon differs greatly as referring back to Table 3.

Furthermore, from the findings, it is also revealed that a larger green area contributes to the higher value of carbon sequestration rate. Therefore, the percentage allocated for the green area has very much influence on the total carbon sequestration rate. The larger green area, the higher value of CSR will be obtained. At this site study area, by referring back to the Figure 3, it is clearly seen that green area covered majority from the total park area with $87 \%$ allocated for the green area as compared to only $13 \%$ allocated for a built-up area. Thus, this percentage of green area covered mostly by turf planting had influenced the total carbon sequestration rate of the park. This assumption is supported by Almeida et al. (2018), stated that urban parks are critical components within the metabolism of cities as well as the core scenes for open-air leisure communal activities. Thus, the concerns for designing a contemporary urban park must consider the size and quality of the green areas aiming to improve the air quality conditions of the nearby urban settlement. On the other hand, landscape design setting or spatial design organization also influence the total carbon sequestration rate. Putra Heights Neighbourhood Park portrayed hybrid design landscape setting with the combination of linear design and curvilinear design landscape planting. Most of the trees, palms and shrubs were organized to be planted in a combination of linear and curvilinear planting according to its spatial functionality.

In summary, it can be concluded that there are key factors that influence the carbon sequestration rate and optimization in applying these factors can contribute to the optimum value of carbon sequestration rate in urban parks. 
i. Planting quantity and specifications.

ii. Percentage of green area and built up area.

iii. Landscape design setting / spatial design organization.

Thus, this will become new design guidelines to the researchers, landscape architects and designer to consider before they start designing any open space or urban parks.

\section{Conclusions}

In urban parks, trees are considered as a green belt asset and function as sinks for excess $\mathrm{CO}_{2}$ in the atmosphere. Trees played an important role in contributing to environmental change and many studies aware of the role of trees in urban environments. Carbon storage of urban trees can lead to a thorough understanding of the ability of urban trees in global carbon that relating to greenhouse emissions. From the findings of the present study, it is clearly shown that urban park green spaces, plant materials specifications and spatial design organization and pattern have greatly influenced the carbon sequestration rate in urban parks. From the context of this site study area, a higher percentage of the green area has much influenced to contribute greater CSR value. Furthermore, plant materials with higher specifications and larger quantities also contribute to the higher carbon sequestration rate. Besides, by having a hybrid design landscape setting also helps in optimizing the CSR value. Consideration of the optimization of these three key factors in designing or enhancing the existing urban parks will help to sequester optimum value or carbon sequestration rate. Thus, by applying these key factors as design guidelines during the design stage or before starting any developments will help the researchers, landscape architects and designers. By having an urban park with an optimum value of carbon sequestration rates will help to strengthen the ecosystem services, therefore, alleviating urban heat island and global warming. These findings will become a novel landscape design guideline to improve environmental quality with cost-effective and environmental friendly. Correlation between plant material group and type of design can be indicative of the carbon sequestration rate. In other words, there is a particular design where specific plant material group sequester high level of carbon. Thus for future research, this raises the importance and need for an effective potential model system to investigate in depth the environmental factors, type of design and plant material group that influence or controlling carbon sequestration rate.

Acknowledgements. The research was supported by the Ministry of Higher Education Malaysia (MOHE) and International Islamic University Malaysia (IIUM) under research grant MOHE18-001-0001.

\section{REFERENCES}

[1] Almeida, C. M. V. B., Mariano, M. V., Agostinho, F., Liu, G. Y., Giannetti, B. F. (2018): Exploring the potential of urban park size for the provision of ecosystem services to urban centres: A case study in São Paulo, Brazil. - Building and Environment 144: 450458.

[2] Department of Statistics, Malaysia (2011): Population Distribution and Basic Demographic Characteristic Report. 
[3] Ehnat, T., Hill, F., Lincoln, L. Y., Menke, K., Town, O., Proctor, R. F. (2011): Neighborhood Business District. - Strategic Urban Forest Management Plan, (Washington Department of Natural Resources): 1-124.

[4] Gratani, L., Varone, L., Bonito, A. (2016): Urban forestry \& urban greening carbon sequestration of four urban parks in Rome. - Urban Forestry \& Urban Greening 19: 20142016.

[5] Mandal, R. A., Jha, P. K., Dutta, I. C., Thapa, U., Karmacharya, S. B. (2016): Carbon sequestration in tropical and subtropical plant species in collaborative and community forests of Nepal. - Advances in Ecology. http://dx.doi.org/10.1155/2016/1529703.

[6] Moumita, D., Ambarish, M. (2015): Carbon sequestration potential, its correlation with height and girth of selected trees in the Golapbag Campus, Burdwan, West Bengal, India. - Indian Journal of Scientific Research 10(1): 53-57.

[7] Nowak, D. J., Crane, D. E. (2013): Carbon storage and sequestration by urban trees in the USA. - Environmental Pollution 116: 381-389.

[8] Othman, R., Abu Kassim, S. Z. (2016): Assessment of plant materials carbon sequestration rate for horizontal and vertical landscape design. - International Journal of Environmental Science and Development 7(6): 410-414.

[9] Pataki, D. E., Carreiro, M. M., Cherrier, J., Grulke, N. E., Jennings, V., Pincetl, S. (2011): Coupling biogeochemical cycles in urban environments: Ecosystem services, green solutions, and misconceptions. - Frontiers in Ecology and the Environment 9(1): 27-36.

[10] Rackley, S. A. (2010): Carbon capture and storage. - Butterwoth-Heinemann Publication, United States of America, pp. 42-49.

[11] Sadeghian, M. M., Vardanyan, Z. (2013): The benefits of urban parks, a review of urban research. - Journal of Novel Applied Sciences: 231-237.

[12] Safaai, N. S. M., Noor, Z. Z., Hashim, H., Ujang, Z., Talib, J. (2011): Projection of $\mathrm{CO}_{2}$ emissions in Malaysia. - Environmental Progress and Sustainable Energy 30(4): 658-665.

[13] Shahbaz, M., Mallick, H., Mahalik, M. K., Sadorsky, P. (2016): The role of globalization on the recent evolution of energy demand in India: Implications for sustainable development. - Energy Economics 55: 52-68.

[14] Shahidan, M. F. (2015): Potential of individual and cluster tree cooling Effect performances through tree canopy density model evaluation in improving urban microclimate. - Current World Environment 10(2): 398-413.

[15] Singh, U. (2013): Carbon capture and storage: An effective way to mitigate global warming. - Current Science 105(7): 914-922.

[16] Tenth Malaysia Plan. (2010): The Economic Planning Unit. - Prime Minister's Department, Putrajaya, 1-451.

[17] Velasco, E., Roth, M., Norford, L., Molina, L. T. (2016): Landscape and urban planning does urban vegetation enhance carbon sequestration? - Landscape and Urban Planning 148: 99-107.

[18] Yin, S., Shen, Z., Zhou, P., Zou, X., Che, S., Wang, W. (2011): Quantifying air pollution attenuation within urban parks: An experimental approach in Shanghai, China. Environmental Pollution 159(8-9): 2155-2163. 